\title{
INTERNALISASI KULTUR PESANTREN \\ PADA PEMBENTUKAN KARAKTER SISWA MELALUI DESAIN BERBASIS KELAS DAN ORGANISASI SEKOLAH
}

\author{
Syamsul Arifin \\ Institut Agama Islam Syarifuddin Lumajang, Indonesia \\ Email: syaif18@gmail.com \\ Mega Silvia \\ Institut Agama Islam Syarifuddin Lumajang, Indonesia \\ Email: putrimega422@gmail.com
}

\begin{abstract}
Abstrak
Globalisasi menimbulkan tantangan yang kuat dan beragam, salah satunya maraknya degradasi moral yang masih sering terjadi dimanamana tidak terkecuali pada jenjang sekolah, untuk itu perlu dilakukan penanaman dan pengembangan nilai-nilai pada peserta didik. Pesantren dianggap mampu menjadi media transformasi keilmuan yang dapat membentuk karakter baik melaui ciri khas dan kebudayaannya yang kuat. Dalam pembentukan karakter peserta didik tidak hanya dilakukan dalam pembelajaran di kelas, tetapi dapat dilakukan melalui pengembangan dari kegiatan lain di sekolah.

Penelitian ini menggunakan metode kualitatif deskriptif, dengan pendekatan studi kasus. Teknik pengumpulan data menggunakan wawancara, observasi dan dokumentasi yang dianalisis secara deskriptif. Sedangkan analisis data yang digunakan adalah reduksi data, penyajian data dan penarikan kesimpulan.Keabsahan data menggunakan tiga teknik yaitu perpanjangan keikutsertaan, ketekunan pengamatan dan triangulasi. Hasil dari penelitian ini menunjukan bahwa; penerapan internalisasi kultur pesantren pada pembentukan karakter siswa meliputi desain berbasis kelas dan desain berbasis organisasi. Adapun Faktor pendukung dan penghambat internalisasi kultur pesantren pada pembentukan karakter siswa dilihat dari pribadi peserta didik itu sendiri, daya dukung dari seluruh warga sekolah dan sarana prasarana.
\end{abstract}

Kata kunci: Kultur Pesantren, Pembentukan Karakter.

\section{Pendahuluan}

Pesantren merupakan salah satu lembaga pendidikan Islam bercorak tradisionalisme yang berakar kuat ditengah-tengah masyarakat.Pesantren juga dikenal sebagai lembaga yang memiliki dasardasar yang kuat dan nilai-nilai strategis dalam pengembangan masyarakat 
Indonesia melalui kebudayaannya yang kental.Pesantren selalu mengafirmasikan dirinya sebagai bagian dari masyarakat dan berdedikasi kembali ke masyarakat. Oleh karena itu pesantren memiliki eksistensi yang kuat dalam setiap aspek lapisan masyarakat.

Sebagai lembaga pendidikan, pesantren membumikan nilai-nilai akhlak sebagai ciri khasnya. Dengan cita-citanya sebagai lembaga transformasi budaya dan keilmuan, pesantren terus berupaya menjadi institusi panutan masyarakat sesuai dengan ajaran Islam. Hal tersebut serupa dengan perkataan Muchtar Buchori, bahwa pesantren merupakan bagian struktural internal pendidikan Islam di Indonesia yang diselenggarakan secara tradisional dan telah menjadikan Islam sebagai pedoman hidup. ${ }^{1}$ Tidak dapat dipungkiri pesantren berkontribusi besar sebagai lembaga pendidikan yang survive terhadap berbagai permasalahan zaman.

Pesantren adalah lembaga asli Islam Indonesia, yang pada saat ini merupakan warisan kekayaan bangsa Indonesia yang terus berkembang dan harus dilestarikan. Pesantren menjadi sarana informasi, sarana komunikasi dan timbal balik secara kultural dengan masyarakat, dan juga tempat pemupukan solidaritas masyarakat. ${ }^{2}$ Pesantren didirikan setelah Islam masuk ke Indonesia. Pesantren mulai dikenal di bumi Nusantara pada abad ke 13-17 M, dan di Jawa terjadi pada abad 15-16 M. Melalui data sejarah tentang masuknya Islam di Indonesia, yang bersifat global tersebut sangat sulit menununjuk dengan tepat tahun dan tempat pertama pesantren didirikan. Namun, dapat dihitung bahwa sedikitnya pesantren telah ada sejak abad 300-400 tahun lampau. Dengan usianya yang panjang tidak dapat diragukan bahwa pesantren telah menjadi bagian budaya

\footnotetext{
${ }^{1}$ Abu Yasid, Paradigma Baru Pesantren (Yogyakarta: IRCiSoD, 2018), 164.

2 Yasid, Paradigma Baru Pesantren, 171.
} 
bangsa dalam bidang pendidikan dan lembaga kemasyarakatan yang mampu memberi konstribusi dengan hasil yang meyakinkan. ${ }^{3}$

Keberadaan pesantren dibuktikan dengan pola pendidikannya yang integral. Tidak hanya fokus pada pendidikan akhlak namun juga aspek lain yang dibutuhkan dalam masyarakat. Sekarang banyak ditemui pesantren dengan model pendidikan yang memadukan sistem tradisional dan modern. Dengan harapan menjadikan pesantren sebagai lembaga yang mampu beradaptasi pada setiap perubahan. Fungsi pesantren sebagai pusat pembentukan akhlak, pencetak manusia Indonesia berdedikasi tinggi dengan spiritualitas, intelektualitas, tangguh dalam kepribadian, berketerampilan dan terbuka terhadap perkembangan zaman. ${ }^{4}$ Fungsi pesantren tidak hanya terbatas pada pendidikan dan dakwah, akan tetapi juga sebagai pusat pembentukan akhlak, pencetak manusia Indonesia berdedikasi tinggi dengan spiritualitas, intelektualitas, tangguh dalam kepribadian, berketerampilan dan terbuka terhadap perkembangan zaman.

Menurut Mujamil Qomar, secara historis fungsi pesantren selalu berubah-ubah sesuai tren masyarakat yang dihadapinya. Pesantren di masa awal ini lebih dominan sebagai lembaga dakwah, dimana lahirnya ulama' dari pesantren dapat membantu masyarakat untuk memahami ajaran agama Islam melalui sebuah pengajian, ceramah atau pengajaran. Sedangkan unsur pendidikan sekedar tambahan dalam misi dakwah. Fungsi pesantren turut berkembang mengikuti arus zaman. Pada zaman kolonial Belanda pesantren berdiri kokoh menjadi pusat penyebaran agama Islam serta menjadi tonggak dalam pertahanan. Agama Islam menjadi pegangan teguh untuk melawan berbagai serangan penjajah Belanda. Dalam sebuah kebudayaan pasti terkandung nilai-nilai didalamnya. Nilai yang dianut akan mampu menentukan sebuah

\footnotetext{
${ }^{3}$ Suparman Yasin dan Yana Sutiana, Kultur Islam Nusantara (Bandung: Pustaka Setia, 2019), 179.

${ }^{4}$ Kompri, Manajemen dan Kepemimpinan Pondok Pesantren,11.
} 
perilaku. Pesantren dengan berbagai fungsinya memiliki kedudukan sentral di tengah masyarakat dan mempertegas, bahwa pesantren telah memberikan sumbangan besar terhadap bangsa Indonesia.

Abdurrahman Wahid (gus dur) memandang pesantren memiliki lingkungan kehidupan yang unik. Tradisi pesantren yang unik dan berkarakter menjadikan pesantren berbeda dari kehidupan pada umumnya. Maka muncullah istilah pesantren sebagai subkultur. ${ }^{5}$ Penggunaan istilah subkultur merupakan usaha pengenalan diri pesantren yang masih belum diakui secara merata, hanya saja karena ketiadaan istilah yang lebih tepat. Dari sisi sosiologis, sebuah subkultur minimal harus memiliki keunikannya sendiri dalam aspek cara hidup yang dianut, pandangan hidup dan tata nilai yang diikuti, serta hirearki kekuasaan intern tersendiri yang ditaati sepenuhnya. Ketiga persyaratan minimal ini terdapat dalam kehidupan pesantren sehingga dirasa cukup untuk mengenakan predikat subkultur pada kehidupan itu. ${ }^{6}$

Budaya diperoleh melalui proses belajar. Tindakan yang dipelajari turun temurun dipelajari dari nenek moyang dan menjadi adat istiadat, antara lain cara makan, minum, berpakaian, berbicara, bertani, bertukang, berelasi dengan masyarakat.7 Nilai-nilai pesantren seperti keikhlasan, ketundukan terhadap guru, kesabaran meniti proses belajar kedisiplinan belajar dan kesediaan untuk hidup sederhana yang dituang oleh olah batin yang memadai, memungkinkan pesantren menjadi sumber nilai kemandirian dan harmoni ditengah-tengah masyarakat. ${ }^{8}$ Oleh karena itu, pesantren dianggap mampu menjadi pelopor lembaga pendidikan yang mengembangkan dan menanamkan nilai-nilai karakter. Sebuah kebudayaan yang terus dijalankan akan menjadi sebuah tradisi yang

\footnotetext{
${ }^{5}$ Alif Pratama Susila, "Studi Analisis Terhadap Pemikiran Abdurrahman Wahid Tentang Agama". Jurnal Aqidah dan Filsafat Islam, vol. 2, no. 1, (tb 2017), 121.

${ }^{6}$ Abdurrahman Wahid, Menggerakkan Tradisi, (Yogyakarta: LKiS 2001), 9-10.

${ }^{7}$ Yasin dan Sutiana, Kultur Islam Nusantara, 23.

8 Muh. Hanif Dhakari, NU Jimat NKRI Jimat Islam Indonesia (Yogyakarta: Pustaka Pesantren, 2013), 8.
} 
sangat berpengaruh pada pembentukan karakter. Pembentukan karakter perlu dilakukan sebagai langkah awal terciptanya generasi bangsa yang berbudi pekerti dan bermoral baik.

Karakter dan akhlak merupakan dua kata yang identik dengan perilaku manusia, baik kepada Allah SWT, sesama manusia, terhadap diri sendiri dan terhadap lingkungan sekitarnya. Semua itu terwujud dalam pikiran, sikap, perasaan, perkataan, dan perbuatnannya berdasarkan norma agama, hukum, tata krama, budaya dan adat istiadat. ${ }^{9}$ Karakter merupakan ciri khas seseorang atau sekelompk orang yang mengandung nilai, kemampuan, kapasitas moral, dan ketegaran dalam menghadapi kesulitan atau tantangan. ${ }^{10}$ Karakter lebih dekat dengan akhlak, yaitu spontanitas dalam bersikap atau perbuatan yang telah menyatu dalam diri manusia sehingga ketika muncul tanpa perlu dipikirkan atau direncanakan sebelumnya. ${ }^{11}$

Waktu terbaik penanaman karakter dimulai sejak dini, agar karakter yang tertanam dapat melekat menjadi sebuah budaya. Baik dan buruknya seseorang mengacu pada karakter dan cara hidup yang sesuai ajaran al-Qur'an dan Nabi Muhammad SAW. ${ }^{12}$ Berikut ini Hadist yang diriwayatkan dari Abdullah bin Amr. Nabi Muhammad SAW bersabda,

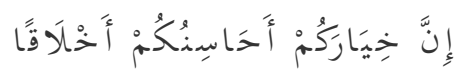

Artinya: Sesungguhnya sebaik-baik orang di antara kalian adalah yang paling baik akhlaknya. (HR. Bukhari).

Begitu pula firman Allah SWT dalam surat Ali Imran yang memerintahkan untuk memiliki karakter baik. ${ }^{13}$

\footnotetext{
${ }^{9}$ Marzuki, Pendidikan Karakter Islam (Jakarta: Amzah, 2019), 21.

${ }^{10}$ Salahudin dan Alkrienciehie, Pendidikan Karakter, 42.

${ }^{11}$ Enni K. Hairuddin, Membentuk Karakter Anak dari Rumah (Jakarta: Media Komputindo, 2014), 2

12 Rosidin, Pendidikan Karkter Khas Pesantren (Tangerang: TSmart, 2017), 2.

${ }^{13}$ AL Qur'an, 3:104.
} 


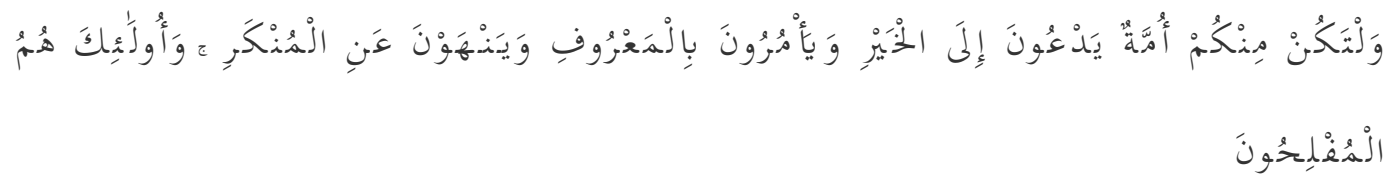

Artinya: Dan hendaklah ada di antara kamu segolongan umat yang menyeru kepada kebajikan, menyuruh kepada yang ma'ruf dan mencegah dari yang munkar, merekalah orang-orang yang beruntung.

Berdasarkan dua rujukan otentik diatas, pendidikan dalam Islam dapat mengembangkan moralitas terhadap Allah SWT, terhadap dirinya dan alam keseluruhan. Pendidikan diarahkan sebagai proses menanamkan nilai-nilai dan budi pekerti yang baik sehingga mereka benar-benar menjadi muttaqin. Dengan demikian, karakter mulia sangat dibutuhkan untuk menjalani kehidupan yang hakiki. Dalam perspektif Islam zakiat daradjat menyebutkan bahwa tujuan pembentukan karakter adalah membentuk manusia dan menjadikan manusia yang sempurna (insan kamil). Singkat kata melahirkan manusia yang mencapai kesuksesan hidup di dunia dan akhirat. Pribadi yang demikian menggambarkan terwujudnya manusia secara kodrati, sebagai makhluk Allah SWT, makhluk individu, makhluk sosial dan makhluk bermoral.

Adapun aspek karakter yang wajib dimiliki oleh anak bangsa, terbukti dalam peraturan perundang-undangan Pasal 3, UU RI Nomor 20 tahun 2003 yang berbunyi: Pendidikan Nasional berfungsi mengembangkan kemampuan dan membentuk watak serta peradaban bangsa yang bermartabat dalam rangka mencerdaskan kehidupan bangsa, bertujuan untuk berkembangnya potensi peserta didik agar menjadi manusia yang beriman dan bertaqwa kepada Tuhan Yang Maha Esa, berakhlak mulia, sehat, berilmu, cakap, kreatif, mandiri, dan menjadi warga negara yang demokratis serta bertanggung jawab. ${ }^{14}$

Keseriusan pemerintah dalam upaya penguatan pendidikan karakter dibuktikan dengan dikeluarkannya Peraturan Presiden (Perpres)

14 Undang-undang Nomor 20 Tahun 2003, Sistem Pendidikan Nasional, Pasal 3 
Nomor 87 Tahun 2017, yang secara teknis dibuat turunannya yaitu Permendikbud Nomor 20 Tahun 2018 tentang Penguatan Pendidikan Karakter pada Satuan Pendidikan Formal. Perpres tersebut mengamanatkan guru sebagai sosok utama yang menjadi teladan pendidikan karakter di sekolah. Mendikbud Muhadjir Effendy mengatakan, guru memiliki tanggung jawab membentuk karakter peserta didik melalui harmonisasi olah hati, olah rasa, olah pikir, dan olah raga. Guru dan tenaga kependidikan harus mampu mengelola kerja sama antara satuan pendidikan, keluarga, dan masyarakat untuk mengobarkan gerakan Nasional revolusi mental. ${ }^{15}$ Adapun nilai-nilai utama karakter yang dikembangkan oleh gerakan penguatan pendidikan karakter (PPK) adalah religius, nasionalis, mandiri, gotong royong dan integritas.

Pendidikan karakter berpijak pada landasan filosofis yang bersumber dari agama, dasar Negara, dan UUD 1945.16 Dalam ranah agama, akhlak memberikan pengaruh terhadap karakter. Pendidikan akhlak yang dipratekkan secara terus menerus akan membentuk karakter seseorang. Dalam ranah dasar Negara dan UUD 1945 bahwa manusia memiliki akal dan kecerdasan untuk mengembangkan segala potensi yang dimilikinya agar memiliki bekal dalam menghadapi berbagai rintangan dan masalah. Berpikir untuk arah yang lebih maju demi kesehjateraan bersama. Adapun landasan sosial pendidikan karakter adalah menekankan pada proses bagaimana berhubungan dengan sesama sebagai mahluk sosial dengan memperhatikan keadaan lingkungan sosialnya sesuai norma dan adat istiadat yang berlaku.

Pembentukan karakter yang baik merupakan cita-cita bangsa yang harus diwujudkan. Proses pendidikan tidak dapat dipisahkan dari

\footnotetext{
${ }^{15}$ Pengelola Web Kemdikbud, http://www.kemdikbud.go.id/main/blog/2017/11/membangun-pendidikankarakter-melalui-keteladanan-guru-Hgn2017, (diakses 9 Juli 2020)

16 Ani Nur Aeni, Pendidikan Karakter Untuk Mahasiswa PGSD (Bandung: Upi Press, 2014), 25
} 
karakter. ${ }^{17}$ Oleh karena itu, proses pendidikan harus mampu memberikan konstribusi dalam perbaikan karakter bangsa. Dengan demikian diharapkan generasi penerus bangsa mampu menerapkan karakter baik dalam setiap aspek kehidupan. Sehingga terwujud bangsa Indonesia yang berkarakter. Proses pendidikan membentuk karakter, pengetahuan dan keterampilan yang dimiliki anak didik. Setiap anak dibimbing untuk mencapai tingkatan yang lebih baik. Karakter yang lebih kuat merupakan bukti dari proses pembentukan yang dilakukan dalam kegiatan pendidikan sebagai penguat dari pendidikan dalam keluarga. Anak akan menjadi pribadi yang kokoh dan tangguh menghasapi kehidupan ini walaupun berbagai pengaruh datang kepadanya.

Hal yang harus dipahami dalam kehidupan adalah menerapkan kemampuan yang kita miliki. Kehidupan ini membutuhkan peran aktif setiap orang agar dapat berlangsung nyata. Peningkatan kualitas hidup memang visi dan misi proses pendidikan dan pembelajaran. Oleh karena itu proses pendidikan mengarahkan anak didik untuk mempunyai karakter agar menyadari bahwa semangat berbagai dengan cara menerapkan atau mengimplementasikan kemampuan ke masyarakat merupakan hal penting.

Derasnya arus globalisasi menimbulkan dampak yang signifikan, tidak terkecuali pada jenjang sekolah. Banyak kita dengar terjadi baku hantam antar pelajar yang menimbulkan banyak korban, penggunaan narkoba, pergaulan bebas, kurangnya rasa hormat terhadap orang tua dan guru, membudayanya rasa tidak jujur, dan lain-lain. Selain itu masih banyak karakter negatif lain yang sekarang terus membudaya di tengahtengah masyarakat. Oleh karena itu sekitar tahun 2010, Presiden Indonesia, Susilo Bambang Yudhoyono, bersama-sama mengajak seluruh rakyat Indonesia untuk rekonstruksi budaya dan karakter luhur bangsa

\footnotetext{
${ }_{17}$ Mohammad Saroni, Pendidikan Karakter tanpa kekerasan (Yogyakarta: Ar-Ruzz media, 2019), 17.
} 
Indonesia yang sudah memudar. Nilai-nilai karakter mulia yang dimiliki bangsa sejak berabad-abad lalu sudah mulai terkikis. ${ }^{18}$ Bangsa yang dapat menjaga karakter mempunyai kemampuan bertahan lebih lebsar dibandingkan dengan bangsa yang kehilangan karakter.

Pendidikan karakter merupakan pendidikan yang terbentuk melalui habitual action yang baik sehingga peserta didik paham, mampu merasakan, dan mau melakukan atas dorongan hati nuraninya. Dengan demikian, pendidikan karakter membawa misi yang sama dengan pendidikan akhlak atau moral. Kepemilikan sebuah karakter merupakan hasil dari proses yang relatif panjang, karakter itu adalah nilai sikap yang dimiliki seseorang. Pendidikan yang baik terbentuk melalui proses yang dibentuk oleh pendidikan itu sendiri dengan pembentukan karakter manusia yang baik pula. Proses pendidikan menekankan upaya untuk mewujudkan hal tersebut.

Berdasarkan studi pendahuluan melalui Majalah Suara PGRI (persatuan guru republik Indonesia) Kabupaten Lumajang menyebutkan bahwa SMK Negeri 1 Lumajang merupakan salah satu sekolah yang mendapat kesempatan untuk di monitoring oleh pengawas Pendidikan Agama Islam Jawa Timur dalam program pengembangan Pendidikan Agama Islam Unggulan. ${ }^{19}$ SMK Negeri 1 Lumajang merupakan sekolah kejuruan dengan system full day school yang mana peserta didik akan lebih difokuskan pada materi kejuruan. Oleh karena itu guru khususnya pendidikan agama Islam yang memiliki sumbangsih besar terhadap pembentukan karakter peserta didik melakukan berbagai upaya untuk mensinergikan nilai-nilai yang terkandung dalam pendidikan karakter melalui pembelajaran dikelas dan kegiatan diluar kelas. Sebagaimana yang kita ketahui, guru adalah agen perubahan (agent of change) untuk

\footnotetext{
18 Marzuki, Pendidikan Karakter Islam, 3.

19PGRI Kabupaten Lumajang, "Sinergitas tarbiyah Pembiasaan PAI Pada Sekolah Dalam Atmosfir Psikologis Pengawas PAI" Jelajah Negeri Bangun Anti Korupsi, Edisi 113, September 2019, 35.
} 
anak didik. ${ }^{20}$ Keberadaan guru dalam proses pendidikan adalah membantu, membimbing dan mendampingi anak didik dalam proses perubahannya. Proses perubahan berarti proses pengondisian agar mencapai tujuan.

Kegiatan ekstrakurikuler rohis (rohani Islam) dan kajian keputrian merupakan sarana meningkatkan pribadi yang religius yang akan membentuk karakter peserta didik. Selain itu ada pembiasaan-pembiasaan yang dilakukan didalam kelas maupun diluar kelas. Sistem seperti inilah yang diterapkan SMK Negeri 1 Lumajang sebagai sarana dan upaya pembentukan karakter peserta didik. Seluruh kegiatan pembiasaan dirancang sebagai strategi dan metode yang tidak hanya meningkatkan intelektual namun lebih pada sikap dan spiritual yang akan menjadi sebuah karakter utuh dari semua pembiasaan-pembiasaan yang terus menerus membudaya.

\section{PEMBAHASAN}

Penerapan Internalisasi Kultur Pesantren pada Pembentukan Karakter Siswa

Berkaitan dengan pendidikan karakter yang berbasis pesantren, pesantren merupakan salah satu tempat yang menjadi kunci keberhasilan pendidikan karakter. Hal ini senada dengan Peraturan Menteri Pendidikan dan Kebudayaan Nomor 23 tahun 2015 mengenai proses pembiasaan dan juga sebuah pembudayaan pendidikan karakter. Karena didalam pesantren tercipta suatu budaya yang terus menerus dilakukan sehingga menjadi kebiasaan atau rutinitas. Ada delapan macam bentukbentuk kultur atau budaya yang ditemui antara interaksi kiai dan santri dalam pondok pesantren, yaitu: ${ }^{21}$

a. Antara kiai dan santri memiliki hubungan akrab, dimana kiai (termasuk guru-gurunya) sangat memerhatikan santri. Hal ini

\footnotetext{
${ }^{20}$ Leken Setyadi, Jadilah Guru Terbaik (Ponorogo: Uwais Inspirasi Indonesia, 2019), 13. ${ }^{21}$ Samsul Nizar, Sejarah Sosial dan Dinamika Intelektual Pendidikan Islam di Nusantara,119120 .
} 
dipengaruhi oleh intensitas dan interaksi kiai dengan santri sangat banyak, setiap hari mereka bertemu karena tinggal di satu kompleks.

b. Adanya kepatuhan (sepanjang tidak bertentangan dengan ajaran agama) dan loyalitas yang tinggi dari santri terhadap kiai, karena menentang kiai dapat menghilangkan keberkahan.

c. Adanya jiwa kesederhanaan yang ditampilkan baik dari kiai, guruguru dan santri.

d. Adanya jiwa kemandirian yang sangat tinggi, seperti: mencuci, membersihkan asrama, dan memasak sendiri di kalangan santri.

e. Adanya jiwa tolong menolong, kerja sama, dan kebersamaan baik dalam hal ibadah maupun hal bekerja.

f. Adanya kedisiplinan yang harus diterapkan dan dilaksanakan tanpa pengecualian, dengan tujuan pemerataan dan pembiasaan seperti tradisi bangun pukul 04.30 WIB atau pukul 05.00 WIB melaksanakan sholat shubuh berjama'ah, atau masuk sekolah pada pukul $08.00 \mathrm{WIB}$, dan seterusnya.

g. Adanya kesabaran dalam kesulitan dan menderita mencapai tujuan. Hal ini akibat latihan puasa, i'tikaf, sholat tahajud, dan amalamamalan lainnya.

h. Adanya restu kiai terhadap santri, yang merupakan pemberian ijazah yang merupakan hak prerogratif seorang kiai. Ijazah model pesantren berbentuk pencantuman nama dalam sebuah daftar transmisi pengetahuan yang dikeluarkan oleh kiai atau gurunya kepada muridnya karena telah menguasai suatu ilmu dalam suatu buk tertentu sehingga dianggap mampu mengajarakan kepada murid lain. ${ }^{22}$

Pembiasaan merupakan salah satu metode dalam pendidikan berbasis kultur pesantren. Kunci keberhasilan pendidikan karakter dapat dilihat dari kebiasaan dalam keseharian yang terbentuk melalui budaya 
sekolah. Nilai-nilai karakter secara sadar ditanamkan atau dibiasakan dalam proses pembiasaan yang dalam jangka panjang akan menjadi kebiasaan atau rutinitas tanpa paksaan. ${ }^{23}$ hal tersebut senada dengan yang disampaikan oleh bapak Zainal Abidin selaku Kepala sekolah SMK Negri 1 Lumajang;

"sebenarnya program pembiasaan ini sudah ada sebelum saya di SMK ini. Untuk program mengaji setiap pagi itu memang rutin, begitupun dengan sholat jama'ah dhuhur dan asar selalu saya tekankan kepada siswa siswi saat penyampaian amanat di upacara. Karena dengan seperti itu siswa siswi akan terbiasa mengaji dan harapan kami akan seterusnya terbiasa dirumahnya. Pada saat event event rapat dengan wali murid juga selalu saya tekankan bahwa siswa siswi di SMK Negeri 1 Lumajang memang kami biasakan seperti itu, dari situ sedikit demi sedikit akan terbentuk karakter religiusnya. Semua itu salah satu upaya kami bagaimana dengan sekolah yang berbasis umum kejuruan namun untuk pengetahuan agamanya terutama mengaji dan sholat bisa seimbang. Zaman sekarang siswa-siswi perlu dibekali ilmu agama yang kuat untuk mengahadapi globalisasi" ${ }^{24}$

Adapun kaitannya dengan kultur pesantren berarti proses pembiasaanya dapat dilakukan melalui kultur pesantren yang sudah ada. Kultur pesantren merupakan segala bentuk kegiatan pesantren yang sudah menjadi kebiasaan dan secara rutin dilaksanakan bersama-sama warga pesantren. Metode pengajaran digunakan di pondok pesantren pada umumnya adalah metode wetonan atau bendongan dan sorogan atau hafalan. ${ }^{25}$ Dalam metode hafalan santri menghafal teks atau kalimat tertentu dari kitab yang dipelajarinya.Untuk memudahkan hafalan ini dilakukan dalam bentuk syi'ir atau nadhom.

Pesantren dipercaya sebagai sebuah lembaga pendidikan Islam dan menjelma menjadi wahana resistensi moral dan budaya atau pewaris tradisi intelektual Islam. Pesantren melakukan penekanan pada upaya

\footnotetext{
${ }^{23}$ Kompri, Manajemen dan Kepemimpinan Pondok Pesantren, 104.

${ }^{24}$ Zainal Abidin, wawancara, Lumajang, 12 Maret 2020, 11.00, Kepala SMK Negeri 1 Lumajang.

${ }^{25}$ Samsul Nizar, Sejarah Sosial dan Dinamika Intelektual Pendidikan Islam di Nusantara (Jakarta: Kencana, 2013), 116.
} 
penanaman nilai-nilai budaya dan perilaku keIslaman. Seperti halnya di pesantren Gontor, salah satu fondasi lain yang membentuk Gontor sebagai pesantren khas adalah Panca Jiwa dan Motto Pondok. Panca Jiwa terdiri dari keihklasan, kesederhanaan, berdikari, ukhuwwah Islamiyah dan kebebasan. Sementara Motto Pondok terdiri atas berbudi tinggi, berbadan sehat, berpengetahuan luas, dan berpikiran bebas. ${ }^{26}$

Dalam membentuk karakter diperlukan suatu desain atau model yang akan menjadi kerangka dalam penerapannya. Seperti halnya di SMK Negeri 1 Lumajang dalam menerapkan kultur pesantren dilakukan melalui dua desain, yaitu:

1. Desain berbasis kelas

Desain berbasis kelas merupakan desain yang berbasis pada hubungan edukatif antara pendidik dan peserta didik dalam melakukan proses belajar mengajar.Proses kegiatan belajar mengajar di dalam kelas memiliki potensi bagi pembentukan karakter siswa. Guru sebagai pendidik karakter kiranya tepat menggambarkan bagaimana relasi antar individu dalam dunia pendidikan sebab menjadi guru itu pada hakikatnya menempatkan diri sebagai suri tauladan bagi para siswa. ${ }^{27}$ Guru memiliki wewenang menggunakan berbagai metode pembelajaran untuk menciptakan suasana belajar mengajar yang nyaman.

Proses pendidikan membentuk karakter, pengetahuan dan keterampilan yang dimiliki anak didik. Setiap anak dibimbing untuk mencapai tingkatan yang lebih baik. Karakter yang lebih kuat merupakan bukti dari proses pembentukan yang dilakukan dalam kegiatan pendidikan sebagai penguat dari pendidikan dalam keluarga. Anak akan menjadi pribadi yang kokoh dan tangguh

\footnotetext{
${ }^{26}$ Savran Billahi dan Idris Thaha, Bangkitnya Kelas menengah Santri (Jakarta: Prenamedia Group, 2018), 45

${ }^{27}$ Doni Koesoma A, Pendidik Karakter di Zaman Keblinger (t.tp: Gramedia Widiasarana, 2016), 136.
} 
menghasapi kehidupan ini walaupun berbagai pengaruh datang kepadanya.

Penerapan didalam kelas dilakukan dengan memberikan sebuah pembiasaan seperti: membaca do'a sebelum dan sesudah belajar, membaca juz 'amma, membaca nadhom-nadhom tauhid dan tajwid, membaca asmaul husna dan menyanyikan mars NU ya lal wathon. ${ }^{28}$ Semua pembiasaan tersebut dilakukan pada pembelajaran pendidikan agama Islam sebelum guru datang, semua itu dilakukan layaknya tradisi di pesantren. Jadi siswa akan lebih mudah memahami materi, misalkan huruf idghom bigunnah, maka dengan membaca nadhom wadhgim bigunnatin biyanmu laidza, jadi hurufnya ada 4 pada lafadz yanmu. Awalnya dibiasakan dari satu nadhom, karena ada beberapa siswa yang memang asing dengan membaca nadhom, kemudian beberapa waktu akhirnya bertambah banyak nadhom yang dibaca. Selain itu siswa-siswi juga dites mengaji terlebih dahulu saat awal pertemuan, dengan tujuan agar diketahui siswasiswi yang bisa mengaji dan yang tidak bisa mengaji. Kemudian ada tambahan waktu bagi yang tidak bisa mengaji. Semua kegiatan tersebut ditekankan kepada siswa-siswi karena dalam pelajaran pendidikan agama Islam lebih utama pada prakteknya terutama dalam hal mengaji. ${ }^{29}$ Karena dalam agama yang paling penting adalah praktek atau akhlak dibandingkan teori.

Berdasarkan hasil dari wawancara yang telah dilakukan dengan guru pendidikan agama Islam, bahwa guru pendidikan agama Islam menggunakan metode pembiasaan yang bernafaskan kultur pesantren dan diintegrasikan dalam proses kegiatan belajar mengajar. Dari beberapa pembiasan tersebut diharapkan menjadi budaya atau kultur yang melekat pada diri siswa. Dalam hal

28 Zainul Ma'arif, wawancara, Lumajang, 11 Maret 2020, 10.00, guru PAI.

${ }^{29}$ Siti Shofiyah, wawancara, Lumajang, 11 Maret 2020, 09.00, guru PAI. 
mengevaluasi kegiatan yang berlangsung dikelas guru pendidikan agama Islam mengkhususkan untuk kelas teknik dengan menyediakan media bantuan berupa foto copy dari beberapa bacaan dengan tujuan mempermudah jalannya kegiatan. ${ }^{30}$

2. Desain Berbasis Organisasi sekolah

Desain berbasis organisasi sekolah merupakan desain yang memiliki aspek lebih luas yaitu melibatkan seluruh pihak dalam sekolah dan sama sama saling membantu dalam membentuk karakter siswa. Karakter anak bangsa merupakan hal yang sangat penting dan berpengaruh dalam kehidupan bermasyarakat, berbangsa dan berNegara. Oleh karena itu, pendidikan karakter harus diperjuangkan sekuat tenaga. Untuk itu perlu ada peran berbagai pihak, termasuk political will dan teladan dari pemerintah. Peran sekolah dalam pembentukan karakter yaitu: ${ }^{31}$

a. Menyusun program pengembangan pendidikan karakter di sekolah yang diarahkan pada perilaku sehari-hari melalui pembelajaran, budaya sekolah, ekstrakurikuler, dan peran serta masyarakat.

b. Mengembangkan dan mengimplementasikan pendidikan karakter di sekolah baik yang telah di programkan maupun yang bersifat spontan.

c. Memberikan contoh atau teladan penerapan karakter yang dikembangkan di sekolah.

d. Mengomunikasikan dan melaporkan perkembangan karakter peserta didik kepada orang tua melalui buku laporan pendidikan.

e. Melakukan monitoring dan evaluasi pelaksanaan pendidikan karakter secara periodik dan berkelanjutan untuk dilaporkan pada dinas pendidikan.

\footnotetext{
30 Zainul Ma'arif, wawancara, Lumajang, 11 Maret 2020, 10.00, guru PAI.

${ }^{31}$ Neolaka, Isu-isu Kritis Pendidikan, 132.
} 
Sama halnya dengan SMK Negeri 1 Lumajang guru pendidikan agama Islam telah menciptakan budaya sekolah yang dibentuk melalui program kegiatan keagamaan dan bekerja sama dengan beberapa pihak yaitu, waka kurikulum dan waka kesiswaan dalam memaksimalkan program tersebut. $^{32}$ Waka kurikulum memberi dukungan lewat menyikronkan jadwal dengan pembiasaan dan juga memberi jadwal sholat dhuha pada hari jum'at yang didampingi masing-masing guru pendidikan agama Islam. Diberi kegiatan sholat dhuha untuk menyeimbangkannya. ${ }^{33}$ Sedangkan waka kesiswaan memberi dukungan dengan turut memeriahkan hari besar dalam Islam dan juga turut memeriahkan. Hal tersebut bertujuan untuk menambah ketebalan iman dan menjadikan peserta didik bangga dengan Islam dengan adanya kemerihan acara. ${ }^{34}$ Dalam hal mengevaluasi program berbasis sekolah guru pendidikan agama Islam menambah tawassul bagi warga sekolah yang sakit atau sedang ada hajat agar menambah kereligiusan dan keyakinan dengan membaca surat al Fatihah bersama. Untuk memperluas kegiatan keagamaan SMK Negeri 1 Lumajang juga bekerjasama dengan beberapa pondok pesantren dalam rangka pesantren ramadhan kilat. Pada ramadhan tahun 2019 SMK Negeri 1 Lumajang mengawali kegiatan dengan pesantren kilat dibeberapa pondok di Lumajang, yaitu pondok pesantren Ar Rahmaniyah Suko, pondok pesantren Al Islah Pulosari dan pondok pesantren Salafiyah Suwandak. Adapun kegiatan pesantren kilat hanya dilakukan selama satu hari satu malam atau sekitar 24 jam oleh siswa siswi kelas X sedangkan kelas XI dan XII dilaksanakan di sekolah. Setiap pondok ditempati 6 kelas kecuali pondok Salafiyah hanya 2 kelas karena hanya menampung putra saja.

\footnotetext{
32 Amila Sholikha, wawancara, Lumajang, 11 Maret 2020, 09.00, guru PAI.

33 Sukur Basuki, wawancara, Lumajang, 14 Maret 2020, 09.00, guru PAI.

34 Susie Hariani, wawancara, Lumajang, 16 Maret 2020, 10.00, waka kesiswaan.
} 
Pembagiannya dilakukan dengan cara bergelombang. Gelombang pertama datang setelah waktu berbuka puasa karena diharuskan mengikuti sholat taraweh di pondok sekaligus melakukan upacara penyerahan dari sekolah. Gelombang kedua datang keesokan harinya setelah sholat taraweh dan melakukan upacara penutupan. Kegiatan yang dilakukan siswa siswi sesuai dengan kegiatan dan kurikulum masing-masing pondok pesantren. Saat di pondok pesantren ada beberapa guru yang langsung memantau sekaligus bekerja sama dengan pengurus pondok pesantren. Alasan yang mendasari kami melakukan program seperti ini adalah karena kami sebagai warga NU yang disitu ada Hari Santri Nasional dengan kami menempatkan siswa siswi di pondok pesantren meskipun hanya dalam waktu 24 jam itu sudah menjadikan mereka sebagai santri. Pada waktu perayaan Hari Santri Nasional kami tekankan bahwa siswa siswi di SMK Negeri 1 Lumajang adalah santri dan harapan kami saat Hari Santri Nasional kami bisa melakukan upacara dengan berpakaian seperti seorang santri. ${ }^{35}$ Peneliti juga melakukan observasi terkait pembiasaan sebelum pelajaran dimulai, yaitu:
a. Hari senin: membaca juz 'amma (jika tidak upacara).
b. Hari selasa: membaca surat waqi'ah.
c. Hari rabu: membaca surat yasin.
d. Hari kamis: membaca juz ‘amma
e. Hari jum'at: membaca istighosah dan tahlil. ${ }^{36}$

Pembacaan pembiasaan tersebut dilakukan sebelum siswasiswi memulai pelajaran pertama dikelas sekitar pukul 06.45 WIB. Saat jam sholat hampir tiba, siswa-siswi sekitar 15 menit sebelum adzan berkumandang saya mengajak siswa-siswi menuju mushollah untuk mempersiapkan sholat jama'ah. Ada siswa yang adzan, kemudian

35 Zainul Ma'arif, wawancara, Lumajang, 17 Maret 2020, 10.00, guru PAI.

36 Observasi, SMK Negeri 1 Lumajang, 13 Maret 2020, 07.00 
guru pendidikan Islam ataupun guru lain yang sedang di mushollah yang menjadi imam sholat, karena jika tidak disiplin terkadang ada yang sholat namun tidak mengumandangkan adzan terlebih dahulu. Dengan begitu akan terbentuk jiwa disiplin dalam menunaikan ibadah sholat, semua itu terbentuk melalui pembiasaan yang lamalama akan menjadi kebiasaan dan membudaya dalam kehidupan mereka sampai bermasyarakat nantinya. ${ }^{37}$ Sesuai hasil observasi yang dilakukan peneliti, menemukan bahwa ada beberapa peserta didik yang sengaja mematikan sepeda motor atau berjalan menunduk saat didepan bapak ibu guru, itu merupakan sifat tawadhu' yang terbentuk dari proses pembentukan karakter.

Desain berbasis kultur sekolah juga dilakukan mlalui komunitas (organisasi) merupakan desain yang terbentuk dalam beberapa perkumpulan siswa siswi yang sama sama membantu dan turut aktif dalam membentuk karakter siswa. Sebuah proses pendidikan perlu dirancang secara sistematis dan memberikan kesempatan bagi siswa untuk mengembangkan potensi dirinya dan tidak terkungkung. ${ }^{38}$ Didalam sebuah sekolah pasti terdapat sebuah organisasi yang menaungi beberapa siswa yang memiliki kesamaan tujuan.

Sama halnya di SMK Negeri 1 Lumajang bahwa dalam mengembangkan karakter siswa tidak hanya terbatas didalam kelas, namun bisa melalui kegiatan di luar kelas.Rohani Islam merupakan salah satu organisasi yang menaungi beberapa ekstrakurikuler keagamaan didalamnya.Untuk kajian keputrian ini dilaksanakan hari jum'at ketika yang laki-laki sholat ke masjid.Pada awalnya kajian keputrian hanya diisi pembacaan juz 'amma dan surat waqi' ah. Kajian keputrian ini sempat berjalan beberapa waktu yaitu tahun 2018,

${ }^{37}$ Zainul Ma'arif, wawancara, Lumajang. 12 Maret 2020, 14.00, guru PAI.

38 Nur Kholik, Terobosan Baru Membentuk Manusia Berkarakter diAbad 21 (Jawa Barat: Edu Publisher, 2020), 125. 
namun semenjak salah satu guru pendidikan agama Islam sakit pada tahun 2019 kajian keputrian semakin tidak rutin, dikarenakan guru pendidikan agama Islam yang perempuan hanya dua. Dan sekarang bu Shofiyah sudah kembali bisa mengajar dan rencanya kajian keputrian akan diisi materi safinatun najah dan risalatul mahid, semoga bisa. Dalam evaluasinya untuk kajian keputrian akan diadakan pengajaran kitab risalatul mahid dan safinatun najah. ${ }^{39}$ Didalam rohis itu kegiatannya ada jum'at 1, jum'at 2, jum'at 3 dan jum'at 4. Kegiatannya ada khitobah, tartil, dibaiyah dan kaligrafi, yang langsung dikoordinir oleh guru pendidikan agama Islam. Dan setiap jum'at manis ada khotmil qur'an. Untuk khotmil qur'an itu dari tahun 2012 SMK Negeri 1 Lumajang sudah mengadakan dan belum ada sekolah-sekolah lain yang mengadakan, tetapi kalau sekarang sudah banyak yang mengadakan khotmil qur'an. Kegiatan tersebut dilaksanakan sebelum tahun 2018 yang mana pada hari hari jum'at dipulangkan jam 10.45 jadi sebelum jum'atan, sehingga karena kurangnya waktu kegiatan tersebut mulai berkurang. Namun seperti al banjari diteruskan setelah jum'atan." 40

Beberapa penjelasan diatas, juga didukung oleh obseravsi peneliti. Kegiatan rohis (rohani Islam) terdiri dari: ${ }^{41}$
a. Ekstrakurikuler al Banjari.
b. Ekstrakurikuler Qiro'ah.
c. Do'a sebelum pembelajaran.
d. Do'a sesudah Pembelajaran.
e. Jum'at Bersih.
f. Khotmil Qur'an.
g. Infak hari jum'at.
h. Perayaan hari besar Islam (PHBI).

\footnotetext{
39 Amila Sholikha, wawancara, Lumajang, 12 Maret 2020, 08.00, guru PAI. ${ }^{40}$ Siti Shofiyah, wawancara, Lumajang, 13 Maret 2020, 10.00, guru PAI.

${ }^{41}$ Observasi, SMK Negeri 1 Lumajang, 13 Maret 2020, 08.00
} 
Pendidikan karakter guru memiliki peranan penting sebagai pelaku utama dalam dunia pendidikan. Guru menjadi teladan atau panutan bagi siswanya dalam menjalani proses pembelajaran di sekolah, terutama dalam hal perilaku atau akhlak. Tujuan dari pendidikan karakter adalah terbentuknya moral, perilaku atau akhlak yang positif. Karakter positif terbentuk melalui pengalaman selama proses pembelajaran berlangsung, oleh karena itu harus dibiasakan atau dilatih.

Konsep pendidikan karakter berbasis kultur pesantren merupakan salah satu desain pembentukan karakter yang ada di sekolah, meskipun yang diterapkan di sekolah melalui kultur sekolah. Tujuannya bukan menyamakan kultur pesantren dengan sekolah, namun mengambil beberapa kultur pesantren yang bisa diinternalisasikan melalui kultur sekolah. Sebab akhir-akhir ini kemelut pendidikan di Indonesia masih terlihat runyam. Banyak kejadian atau perilaku-perilaku yang tidak sepatutnya terjadi dalam proses pembelajaran, oleh karenanya dibutuhkan ikhtiar bersama untuk bangkit membentuk bangsa yang berkarakter cerdas serta menguasai iman takwa (imtak) dan ilmu pengetahuan dan teknologi serta sains (ipteks). Pesantren merupakan lembaga pendidikan yang sudah lebih dulu concern menerapkan pendidikan karakter bagi santrinya.Santri dituntut untuk memiliki tanggung jawab dalam setiap perbuatan, kerja keras, sederhana, mandiri, jujur, berwawasan luas dan mampu menempatkan diri dengan baik. ${ }^{42}$

Sisi kearifan lokal di pesantren dapat dijadikan rujukan mengenai pengembangan dan pembentukan karakter, karena pendidikan di pesantren sangat jauh mengedepankan akhlak atau karakter bagi santrinya.Bahkan pesantren disinyalir merupakan salah satu lembaga pendidikan karakter yang meliputi tiga peran sekaligus, yaitu sebagai lembaga pendidikan informal, nonformal, dan formal.

42 Ali, Paradigma Pesantren, 67. 
Tabel 1. Matrik Tentang Penerapan Kultur Pesantren Pada Pembentukan Karakter Siswa

\begin{tabular}{|c|c|c|c|}
\hline No. & $\begin{array}{l}\text { Sub Fokus } \\
\text { Penelitian }\end{array}$ & Komponen & Temuan \\
\hline 1. & $\begin{array}{l}\text { Penerapan } \\
\text { Internalisasi Kultur } \\
\text { Pesantren }\end{array}$ & $\begin{array}{l}\text { 3. Desain } \\
\text { Berbasis } \\
\text { Komunitas } \\
\text { (organisasi } \\
\text { ) }\end{array}$ & 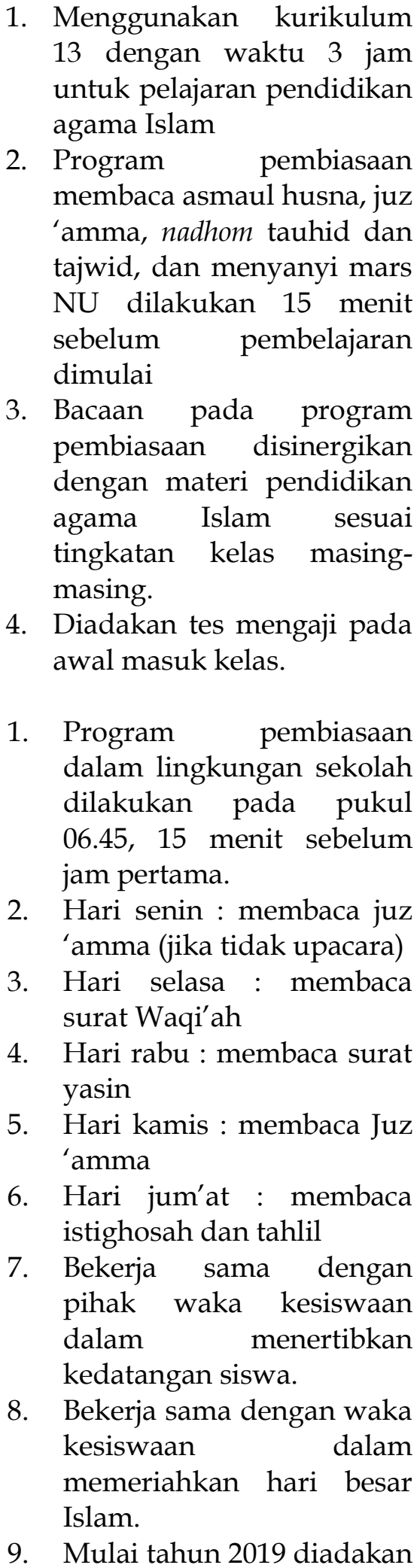 \\
\hline
\end{tabular}




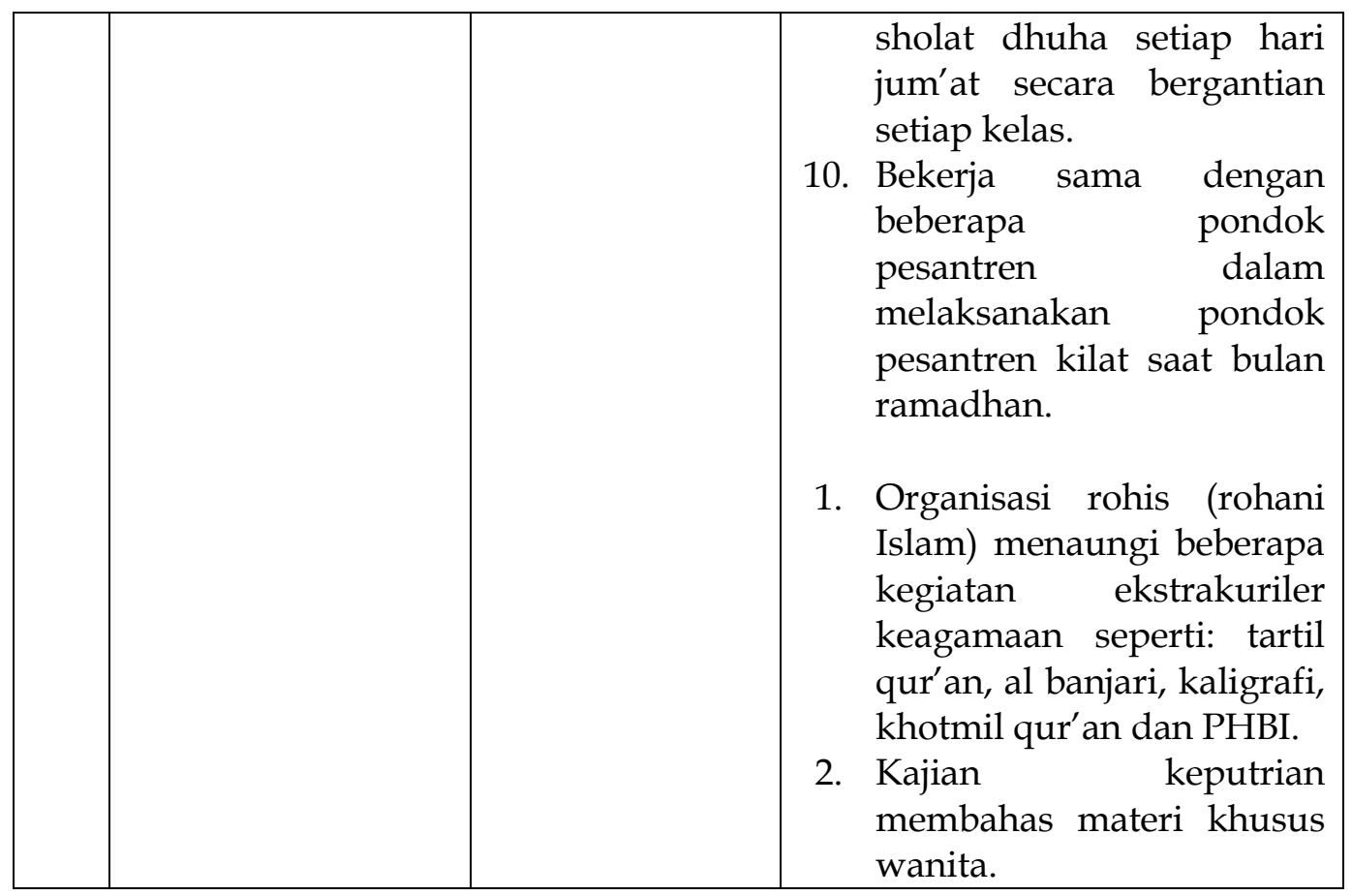

\section{Faktor Pendukung dan Penghambat Internalisasi Kultur Pesantren pada} Pembentukan Karakter Siswa

Menurut Ratnawati yang mempengaruhi pendidikan dan pembentukan karakter meliputi faktor internal dan faktor eksternal. ${ }^{33}$ Adapun penjabarannya sebagai berikut:

1. Faktor Internal

Faktor internal merupakan faktor yang dapat menjadi pendukung ataupun penghambat yang berasal dari dalam individu. Faktor ini berkaitan dengan soft kill interpersonal (keterampilan seseorang dalam berhubungan dengan orang lain) dan intrapersonal (keterampilan dalam mengatur dirinya sendiri) yang dimiliki siswa.

2. Faktor Eksternal

Faktor eksternal merupakan faktor yang di pengaruhi oleh lingkungan sekitar.faktor eksternal yang berperan penting dalam pembentukan karakter peserta didik, antara lain: lingkungan sekolah, lingkungan keluarga, lingkungan masyarakat.

\footnotetext{
${ }^{43}$ Sofyan Mustoip.et al, Implementasi Pendidikan Karakter (Surabaya: CV. Jakad Publishing, 2018), 51-52.
} 
Berdasarkan paparan di atas karakteristik peserta didik merupakan sebuah jati diri yang dimiliki peserta didik sebgai potensi sejak lahir, dan berkembang melalui proses pendidikan tentang sosialisasi nilai-nilai. Dengan mengetahui karakteristik peserta didik maka akan ditemukan cara efektif membentuk karakter peserta didik melalui proses belajar mengajar yang merujuk pada kultur pesantren. Kita selalu mengarahkan, membimbing dan mendampingi anak-anak sehingga karakter dasar yang dimiliki dapat berkembang secara signifikan sebagai karakter yang dibutuhkan masyarakat.

Karakter peserta didik dapat dibentuk melalui proses pendidikan. Dalam perkembangannya, karakteristik peserta didik dipengaruhi oleh faktor internal (pembawaan) dan faktor eksternal (lingkungan keluarga, sekolah, dan masyarakat) yang terus berlanjut sepanjang hayat.Sama halnya di SMK Negeri 1 Lumajang ada beberapa faktor dari siswa itu sendiri (internal) atau dari pihak sekolah (eksternal) yang mendukung dan menghambat jalannya program pembiasaan tersebut.pada awal program pembiasaan tersebut terlaksana, ada beberapa hambatan sebenarnya, yaitu masalah waktu jadi siswa, semua jajaran guru maupun kepala sekolah harus berangkat lebih awal semua, karena pembiasaan dimulai jam 06.45 WIB dan pada waktu bersamaan gerbang sekolah ditutup. Semua itu butuh adaptasi karena merupakan hal baru. Kemudian apa yang akan dibaca itu masih belum terjadwalkan, jadi pada tahun 2011 itu yang dibaca hanya juz 'amma dan istighosah. Pada waktu itu istighosah masih terdengar asing bagi beberapa orang. Selanjutnya bagi yang non muslim, dengan alternatif pilihan antara tetap diam dikelas atau menunggu diluar kelas selama pembiasaan berlangsung. Untuk yang berbasis kultur sekolah hambatan yang begitu besar menurut kami adalah sarana prasarana yang kurang memenuhi yaitu mushollah dengan jumlah siswa sebanyak kurang lebih 1.600 siswa-siswi, namun untuk ukuran mushollahnya kecil, jadi untuk sholat berjama'ah harus bergantian. Untuk 
sekarang mushollah dalam tahap pelebaran.Semoga dengan ini kami bisa melaksanakan sholat jama'ah dengan serentak. ${ }^{44}$

untuk faktor pendukung didalam kelas salah satunya jumlah jam pendidikanagama Islam dalam kurikulum 2013 adalah 3 jam, 1 jam untuk literasi jadi sangat cukup untuk dilakukan pembiasaan-pembiasaan tersebut. Dan juga siswa-siswi sudah terbiasa melakukan pembiasaanpembiasaan tersebut di sentral jadi saat diterapkan dikelas mudah untuk diatur. Untuk faktor penghambat didalam kelas dipetakan berdasarkan beberapa jurusan, karena setiap jurusan karakter siswanya berbeda-beda. Misalkan kelas administrasi perkantoran yang mana siswa-siswinya jeli dalam tulis menulis, tanpa disuruh mereka punya catatan pribadi atau foto copy dari nadhom yang dibaca, itu tidak menjadi penghambat bagi mereka, berbeda dengan kelas teknik yang banyak ke lapangan, terkadang mereka tidak membawa buku atau bacaan pada saat pembiasaan. Terkadang waktu 1 jam untuk pembiasaan berkurang karena mereka harus meminjam buku ke kelas lain. Oleh karena itu untuk kelas tekhnik kami sediakan foto copy dari beberapa bacaan yang dibaca. 45

Mulai tahun 2018 sampai sekarang kegiatan rohis sudah bisa maksimal karena selain tambahan waktu kami juga memanggil ustad dari luar sekolah untuk melatih beberapa ekstrakurikuler seperti tartil alQur'an dan albanjari, selain itu para alumni juga turut membantu. Bahkan dari anggota al banjari SMK ada yang beberapa sudah alumni. Alhamdulillah kami sudah bisa mengikuti beberapa event festival al banjari. Untuk yang menjadi kendala sebenarnya tidak terlalu besar hanya saja terletak pada kekompakan anggota, terkadang saat kegiatan hanya beberapa anggota yang turut membantu. ${ }^{46}$

Kepala sekolah juga memberi pernyataan terkait sarana dan prasarana bahwa SMK Negeri 1 Lumajang selalu berupaya melakukan

44 Zainul Ma'arif, wawancara, Lumajang, 13 Maret 2020, 15.00, guru PAI.

45 Zainul Ma'arif, wawancara, Lumajang, 19 Maret 2020, 10.16, guru PAI.

46 Maulana Ishaq, wawancara, Lumajang, 19 Maret 2020, 13.00, Pembina Rohis 
perbaikan dari segi apapun yaitu sarana prasarana maupun perkembangan siswa-siswi. Dana pelebaran mushollah ini didapatkan dari infak siswa dan guru pada setiap harinya, ada pula beberapa orang tua yang menyumbang material bangunan. Pada saat rapat dengan wali murid memang saya singgung untuk dana pelebaran mushollah ini. Ada beberapa panitia yang sengaja mendatangi wali murid untuk meminta dana seikhlasnya. Setelah semua terkumpul akhirnya mendapatkan nominal yang cukup besar yaitu 12.000.000. saya mengatakan pada wali murid bahwa di SMK Negeri 1 Lumajang rutin melaksanakan sholat jama'ah dhuhur dan asar namun tidak bisa serentak bersamaan karena kendala ukuran mushollah yang kecil. Oleh karena itu kami sengaja menyediakan wadah bagi yang ingin menyumbang. ${ }^{47}$

Tabel 2. Matrik Tentang Faktor Pendukung dan Penghambat

Kultur Pesantren Pada Pembentukan Karakter Siswa

\begin{tabular}{|c|c|c|c|}
\hline No. & $\begin{array}{l}\text { Sub Fokus } \\
\text { Penelitian }\end{array}$ & Komponen & Temuan \\
\hline 1. & $\begin{array}{l}\text { Faktor -faktor } \\
\text { dalam penerapan } \\
\text { Internalisasi Kultur } \\
\text { Pesantren pada } \\
\text { Pembentukan } \\
\text { Karakter Siswa }\end{array}$ & $\begin{array}{l}\text { 1. Faktor } \\
\text { Pendukung } \\
\text { (1)Internal } \\
\text { (2) Eksternal }\end{array}$ & $\begin{array}{l}\text { 1. } \begin{array}{l}\text { Pengkondisian kelas } \\
\text { jurusan bisnis } \\
\text { manjemen lebih } \\
\text { mudah. }\end{array} \\
\text { 1. } \begin{array}{l}\text { Daya dukung dari } \\
\text { kepala sekolah dan }\end{array} \\
\text { waka kesiswaan. } \\
\text { 2. Waktu jam pelajaran } \\
\text { Pendidikan Agama } \\
\text { Islam dalam K13 } \\
\text { berjumlah 3 jam. 1 jam } \\
\text { untuk literasi. } \\
\text { 3. } \begin{array}{l}\text { Daya dukung dari } \\
\text { alumni dalam } \\
\text { kegiatan rohis. }\end{array}\end{array}$ \\
\hline & & $\begin{array}{l}\text { 2. Faktor } \\
\text { Penghambat } \\
\text { (1) Internal }\end{array}$ & $\begin{array}{l}\text { 1. Pengaturan kelas } \\
\text { teknik yang lebih } \\
\text { rumit. }\end{array}$ \\
\hline
\end{tabular}

47 Zainal Abidin, wawancara, Lumajang, 12 Maret 2020, 11.00, kepala SMK Negeri 1 Lumajang. 


\begin{tabular}{|l|l|l|}
\hline & (2) Eksternal & $\begin{array}{l}\text { 2. } \\
\text { Ada beberapa anggota } \\
\text { rohis yang kurang } \\
\text { kompak. }\end{array}$ \\
& $\begin{array}{l}\text { 1. Sarana mushollah } \\
\text { yang kurang } \\
\text { memenuhi. }\end{array}$ \\
& 2. $\begin{array}{l}\text { Butuh adaptasi waktu } \\
\text { dalam menjalankan } \\
\text { program pembiasaan. }\end{array}$ \\
\hline
\end{tabular}

\section{Kesimpulan}

Internalisasi kultur pesantren pada pembentukan karakter siswa ditanamkan guru dengan cara mensinergikan bacaan pembiasaan dengan materi pelajaran melalui desain berbasis kelas dan berbasis komunitas (organisasi), yang mana guru pendidikan agama Islam bekerja sama dengan Waka Kurikulum dan Waka Kesiswaan dalam melancarkan program pembiasaan di lingkungan sekolah. Adapun faktor pendukunng internalisasi kultur pesantren pada pembentukan karakter siswa berasal dari faktor internal dan eksternya. Faktor internalnya adalah pengaturan kelas bisnis manajemen lebih mudah. Sedangkan faktor eksternalnya daya dukung dari waka kesiswaan dan waka kurikulum serta waktu jam pendidikan agama Islam dalam kurikulum 2013 yang lebih banyak yaitu tiga jam sehingga sangat memungkinkan melakukan pembiasaan didalam kelas. Adapun faktor penghambatnya adalah pengaturan kelas teknik lebih sulit sehingga membutuhkan tenaga ekstra bagi guru yang mengajar. Dan butuh adaptasi waktu dalam menjalankan program pembiasaan dan sarana prasarana yang kurang memenuhi.

\section{Referensi}

Al-Qur'an dan Terjemahannya

Aeni Ani Nur, 2014, Pendidikan Karakter Untuk Mahasiswa PGSD, Bandung: Upi Press.

A'la Abd, 2006, Pembaharuan Pesantren, Yogyakarta: Pustaka Pesantren.

Ali Suryadharma, 2013, Paradigma Pesantren, Malang: UIN Maliki Press.

Billahi Savran dan Idris Thaha, 2018, Bangkitnya Kelas menengah Santri, Jakarta: Prenamedia Group.

Dhakari Muh. Hanif, 2013. NU Jimat NKRI Jimat Islam Indonesia, Yogyakarta: Pustaka Pesantren. 
Dimyati, Johni, 2013, Metodologi Penelitian Pendidikan dan Aplikasinya, Jakarta: Kencana.

Hairuddin Enni K, 2014, Membentuk Karakter Anak dari Rumah, Jakarta: PT Elex Media Komputindo.

Marzuki, 2019, Pendidikan Karakter Islam, Jakarta: Amzah.

Mustoip Sofyan.et al, 2018, Implementasi Pendidikan Karakter, Surabaya: CV. Jakad Publishing.

Nizar, Samsul. 2013, Sejarah Sosial dan Dinamika Intelektual Pendidikan Islam di Nusantara, Jakarta: Kencana.

Neolaka Amos, 2019, Isu-Isu Kritis Pendidikan, Jakarta: Prenadamedia Group.

PGRI Kabupaten Lumajang, 2019, Sinergitas tarbiyah Pembiasaan PAI Pada Sekolah Dalam Atmosfir Psikologis, Pengawas PAI Jelajah Negeri Bangun Anti Korupsi, Edisi 113.

Rosidin, 2017, Pendidikan Karkter Khas Pesantren, Tangerang: TSmart.

Rukajat Ajat, 2018, Pendekatan Penelitian Kuantitatif, Yogyakarta: Deepublish.

Saroni Mohammad, 2019, Pendidikan Karakter tanpa kekerasan, Yogyakarta: Ar-Ruzz media.

Semiawan R Conny, Metode Penelitian Kualitatif, t.tp: Grasindo.

Kholik Nur, 2020, Terobosan Baru Membentuk Manusia Berkarakter diAbad 21, Jawa Barat: Edu Publisher.

Kompri, 2018, Manajemen dan Kepemimpinan Pondok Pesantren, Jakarta: kencana.

Koesoma Doni A, 2016, Pendidik Karakter di Zaman Keblinger, t.tp: Gramedia Widiasarana.

Sukiyat, 2020, Strategi Implementasi Pendidikan Karakter, Surabaya: CV Jakad Media Publishing.

Setyadi Leken, 2019, Jadilah Guru Terbaik Ponorogo: Uwais Inspirasi Indonesia.

Sugiyono, 2017, Metode Peneltian, Bandung: Alfabeta. 
Siyoto Sandu dan Ali Sodik, 2015, Dasar Metodologi Penelitian, Yogyakarta: Literasi Media Publishing.

Undang-undang Nomor 20 Tahun 2003, Sistem Pendidikan Nasional, Pasal 3

Yasid, Abu. 2018. Paradigma Baru Pesantren, Yogyakarta: IRCiSoD.

Yasin Suparmandan, Yana Sutiana, 2019, Kultur Islam Nusantara, Bandung: Pustaka Setia.

Wahid Abdurrahman, 2001, Menggerakkan Tradisi, Yogyakarta: LKiS.

Yasid Abu. 2018, Paradigma Baru Pesantren, Yogyakarta: IRCiSoD. 